\title{
Uji Efektivitas Inokulum Fungi Mikoriza Arbuskula Terhadap Pertumbuhan Bibit Jati (Tectona Grandis Linn. F)
}

\section{The Effectivity Arbuscular Mycorrhizal Fungi Inoculum in Tectona grandis Linn. F}

Kartika Megawati ${ }^{\mathrm{a}}$, Sri Wilarso Budi ${ }^{\mathrm{b}}$ Irdika Mansur $^{\mathrm{b}}$

${ }^{a}$ Mahasiswa pascasarjana program studi Silvikultur Tropika, Institut Pertanian Bogor, Kampus IPB Darmaga, Bogor 16680

${ }^{\text {b}}$ Departemen Silvikultur, Fakultas Kehutanan, Institut Pertanian Bogor, Kampus IPB Darmaga, Bogor 16680

\section{Article Info:}

Received: 22 - 01 - 2018

Accepted: $13-11-2018$

Keywords:

Acaulospora, endomycorrhiza, glomus clarum.

Corresponding Author: Kartika Megawati Pascasarjana program studi Silvikultur Tropika, Institut Pertanian Bogor, Kampus IPB Darmaga, Bogor 16680; Email: kartika.amf@gmail.com

\begin{abstract}
Arbuscular mycorrhizal fungi is a phylum of Glomeromycota. Arbuscular mycorrhizal fungi (AMF) propagule are spores, mycor-rhizal fungal hyphae and infected root fragments. The aims of this research were to analyze the effectivity of root inoculum of AMF to enhance teak (Tectona grandis Linn F.) seedling growth. The research was used complete randomized design (CRD)-split plot design. The main plot was root inoculum of AMF, sub plot is a media sterilization and media is not sterilized. The results showed that root inoculum of AMF and media effectively improved teak growth, especially in height, diameter, and shoot dry weight. Root inoculum of AMF is able to be used as the source of inoculum for the growth teak seedling. Fresh inoculum was found to be better than root inoculum stored at room temperature and root inoculum stored at refrigerator temperature $\left(5^{\circ} \mathrm{C}\right)$. Storage of root inocu-lum at room temperature and refrigerator temperature $\left(5^{\circ} \mathrm{C}\right)$ for two weeks decreased the effectiveness of inoculum. Type of mixed inoculum and inoculum of Acaulospora sp. root resulted in better growth compared with $G$. clarum root inoculum.
\end{abstract}

How to cite (CSE Style $8^{\text {th }}$ Edition):

Megawati K, Budi SW, Mansur I. Uji efektivitas inokulum fungi mikoriza arbuskula terhadap pertumbuhan bibit jati (Tectona Grandis Linn. F). JPSL 9(3): 587-595. http://dx.doi.org/10.29244/jps1.9.3.587-595.

\section{PENDAHULUAN}

\section{Latar Belakang}

Jati (Tectona grandis Linn. F) merupakan salah satu jenis pohon dari famili Verbenaceae, yang memiliki kualitas kayu dan nilai jual yang sangat tinggi. Jati merupakan pohon penghasil kayu utama dunia yang sebagian besar dimanfaatkan untuk berbagai kepentingan serta mudah dibudidayakan (Nusantara 2011). Fungi mikoriza arbuskula (FMA) merupakan kelompok fungi yang tergolong dalam filum Glomeromycota, hidup secara simbiosis dengan akar tanaman (Iffis et al. 2014). Melalui simbiosisnya, tanaman inang mendapatkan nutrisi dari fungi sedangkan FMA menerima karbohidrat dari tanaman inangnya (Gutjahr 2014). Bagi tanaman inang, FMA sangat menguntungkan dalam penyerapan nutrisi dan air, toleransi terhadap kekeringan, terhambatnya infeksi oleh organisme penyakit (Hajoeningtijas 2009), meningkatkan pertumbuhan bibit, tinggi pohon dan hasil tanaman (Kapulnik 2010), memperbaiki agregasi tanah (Rillig et al. 2002), mengatasi cekaman non-hayati dan hayati pada tanaman dan meningkatkan produktivitas ekosistem (Smith et al. 2010).

Inokulan FMA dapat bersumber dari spora, akar yang terinfeksi FMA dan potongan hifa (Smith dan Read 2008). Khastini et al. (2007) melaporkan potongan akar segar bawang daun jenis FMA Glomus manihotis dan 
Acaulospora tuberculata meningkatkan pertumbuhan tapak dara pada pemberian fosfat $50 \%$ dibandingkan tanpa FMA. Penelitian Daru et al. (2007) menjelaskan bahwa inokulasi FMA dalam bentuk potongan akar dapat meningkatkan berat kering pucuk rumput signal sebesar $0.15 \mathrm{~g}$ dan berat kering akar $0.06 \mathrm{~g}$ dibandingkan tanaman tanpa FMA. Sejauh ini belum pernah dilaporkan penggunaan inokulum akar bermikoriza dalam meningkatkan pertumbuhan bibit jati. Oleh sebab itu, penelitian ini dirancang dengan tujuan untuk menguji efektivitas inokulum akar pada pertumbuhan bibit jati.

\section{Tujuan}

Tujuan penelitian ini adalah untuk menguji beberapa tipe inokulum akar pada media tanam steril dan tidak steril serta pengaruh perlakuan kombinasi terhadap pertumbuhan bibit jati. Manfaat penelitian ini adalah memberikan data-data dan informasi mengenai tipe inokulum akar yang dapat digunakan untuk meningkatkan pertumbuhan bibit jati.

\section{METODE}

\section{Lokasi dan Waktu Penelitian}

Penelitian ini dilaksanakan mulai bulan Desember 2016 sampai dengan Juni 2017. Pembibitan jati dilakukan di rumah kaca I SEAMEO BIOTROP. Identifikasi spora dilaksanakan di Laboratorium Silvikultur SEAMEO BIOTROP, Laboratorium Mikoriza dan Kualitas bibit Departemen Silvikultur Fakultas Kehutanan Institut Pertanian Bogor.

\section{Prosedur penelitian}

\section{Persiapan media tanam}

Media tanam yang digunakan adalah campuran tanah dan arang sekam dengan perbandingan (4:1). Media tanam tidak steril disemprot dengan campuran larutan fungisida benomyl $50 \%$ dan streptomisin sulfat $25 \%$, dan untuk media tanam steril disterilisasi dengan menggunakan autoklaf pada suhu $121^{\circ} \mathrm{C}$ selama 60 menit. Selanjutnya media tanam dimasukkan ke dalam polibag ukuran 10x15 cm.

\section{Inokulasi dan Pemeliharaan}

Bibit jati pasca aklimatisasi produk Laboratorium Kultur jaringan SEAMEO BIOTROP diinokulasi dengan inokulum akar FMA ( 2 g/tanaman). Inokulum yang digunakan adalah inokulum akar FMA hasil produksi dari sistem hidroponik nutrient film technique (Tabel 1).

Tabel 1 Persentase kolonisasi pada akar tanaman inang dalam sistem hidroponik nutrient film technique yang digunakan untuk inokulasi bibit jati

\begin{tabular}{ccccc}
\hline \multirow{2}{*}{ Jenis FMA } & \multicolumn{4}{c}{ Persentase Kolonisasi akar tanaman $(\%)$} \\
\cline { 2 - 5 } & $\mathrm{T} 1$ & $\mathrm{~T} 2$ & $\mathrm{~T} 3$ & $\mathrm{~T} 4$ \\
\hline M0 & 0 & 0 & 0 & 0 \\
\hline M1 & 19.76 & 18.66 & 7.76 & 4.66 \\
\hline M2 & 3.99 & 2.86 & 4.66 & 2.44 \\
\hline M3 & 4.88 & 3.77 & 4.66 & 3.55 \\
\hline
\end{tabular}

FMA: fungi mikoriza arbuskula; MST: minggu setelah tanam; M0: kontrol; M1: inokulum campuran; M2: Glomus clarum; M3: Acaulospora sp.; T1: kudzu (Pueraria javanica); T2: kangkung (Ipomoea aquatica); T3: tomat (Lycopersicum esculentum L.); T4: sengon (Falcataria moluccana).

Seluruh bibit diletakkan di rumah kaca selama 6 bulan. Penyiraman dilakukan 2 kali sehari yaitu pada pagi dan sore hari. 


\section{Metode Pengumpulan Data}

Pengumpulan data diperoleh dari parameter pengamatan, yaitu :

a. Pertambahan tinggi bibit $(\mathrm{cm})$

Pengukuran pertambahan tinggi bibit dilakukan setelah penanaman di polibag, dilakukan setiap 2 minggu sekali sampai bibit berumur 6 bulan. Pengukuran dilakukan menggunakan penggaris. Semai diukur mulai dari pangkal batang sampai titik tumbuh pucuk bibit.

b. Pertambahan diameter bibit $(\mathrm{mm})$

Pengukuran pertambahan diameter bibit dilakukan setelah penanaman di polibag, dilakukan setiap 2 minggu sekali sampai bibit berumur 6 bulan.

Pengukuran dilakukan menggunakan kaliper, bibit diukur pada ketinggian sekitar $1 \mathrm{~cm}$ di atas pangkal batang bibit.

c. Berat kering pucuk dan berat kering akar

Pengukuran dilakukan pada saat akhir pengamatan dengan memotong bagian pucuk dan akar dari sampel tanaman, kemudian masing-masing bagian tanaman tersebut dimasukkan ke dalam kertas terpisah lalu dikeringkan dalam oven dengan suhu $70^{\circ} \mathrm{C}$ selama 72 jam sampai tercapai bobot kering konstan. Setelah sampel bagian tanaman dikeringkan selanjutnya ditimbang dengan timbangan analitik. Dari hasil penimbangan tersebut akan didapat biomassa pucuk, biomassa akar dan total berat kering tanaman.

d. Nisbah pucuk akar (NPA)

Nisbah pucuk akar didapat dari membandingkan biomassa pucuk bibit dengan biomassa akar bibit kering.

e. Persentase kolonisasi akar $(\%)$

Persentase kolonisasi akar dapat dihitung dengan rumus sebagai berikut (Nusantara et al. 2012):

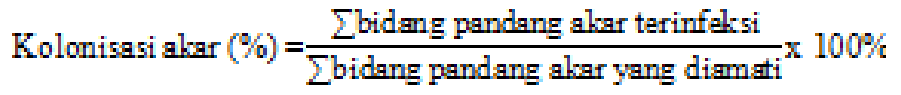

\section{Rancangan Percobaan dan Analisis Data}

Rancangan percobaan yang digunakan dalam penelitian uji efektivitas inokulum pada tanaman Jati adalah rancangan petak terbagi (split plot design). Petak utama (jenis inokulum); tanpa inokulum (M0), inokulum akar campuran segar (M1), inokulum akar campuran simpan suhu ruang $26^{\circ} \mathrm{C}$ selama 2 minggu (M2), inokulum akar campuran simpan suhu lemari pendingin $5^{\circ} \mathrm{C}$ selama 2 minggu (M3), inokulum akar Glomus clarum segar (M4), inokulum akar Glomus clarum simpan suhu ruang $26^{\circ} \mathrm{C}$ selama 2 minggu (M5), inokulum akar Glomus clarum simpan suhu lemari pendingin $5^{\circ} \mathrm{C}$ selama 2 minggu (M6), inokulum akar Acaulospora sp. segar (M7), inokulum akar Acaulospora sp. simpan suhu ruang $26^{\circ} \mathrm{C}$ selama 2 minggu (M8), inokulum akar Acaulospora sp. simpan suhu lemari pendingin $5^{\circ} \mathrm{C}$ selama 2 minggu (M9), Anak petak (media tanam); steril (S1), tidak steril (S2). Dari 2 faktor tersebut terdapat 18 kombinasi perlakuan, tiap perlakuan dilakukan ulangan sebanyak 3 kali sehinggga terdapat 54 tanaman yang diamati. Data hasil dianalisis menggunakan sidik ragam program SAS 9.4. Jika perlakuan berpengaruh nyata dilakukan uji lanjut Duncan $5 \%$.

\section{HASIL DAN PEMBAHASAN}

\section{Tinggi dan diameter tanaman}

Pemberian inokulum akar FMA memberikan respon terhadap pertambahan tinggi dan diameter bibit jati. Hasil pengamatan pada parameter tinggi (Gambar 1) dan diameter (Gambar 2) menunjukkan bahwa pemberian inokulum akar FMA memberikan pertambahan tinggi dan diameter bibit jati yang beragam. 


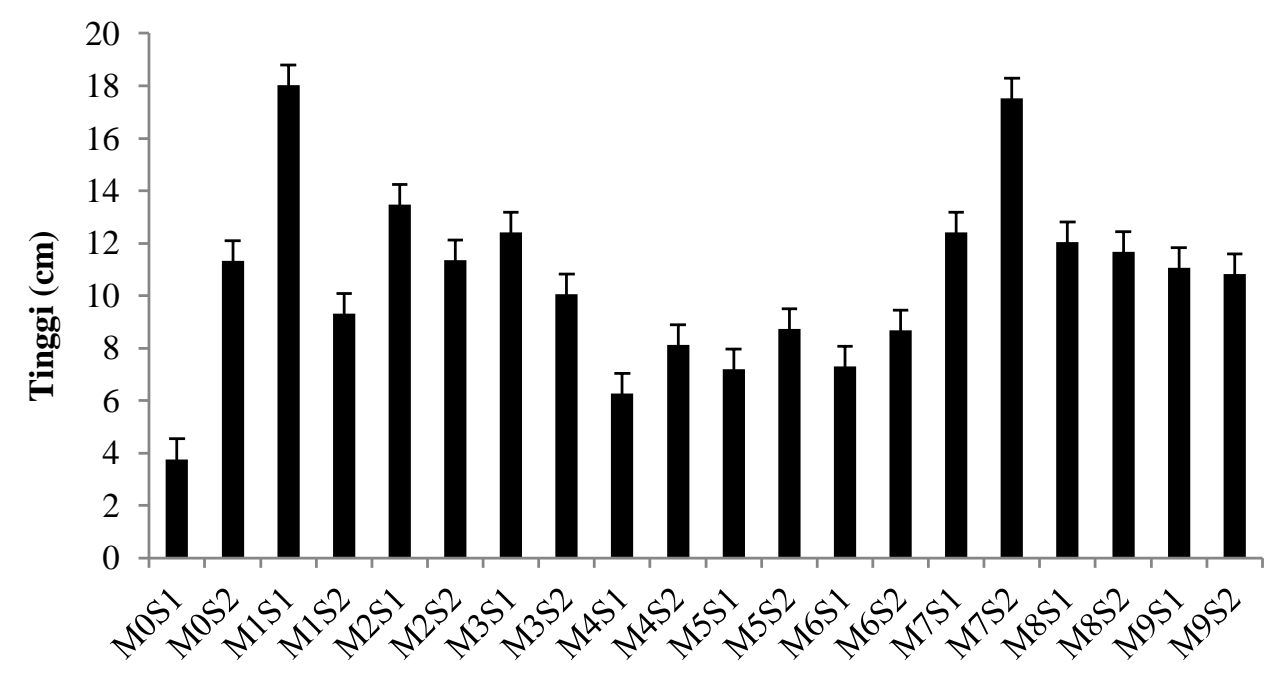

Perlakuan

Gambar 1 Pengaruh interaksi tipe inokulum dan media tanam terhadap pertambahan tinggi bibit jati (Tectona grandis) umur 24 minggu setelah tanam; M0: tanpa inokulum; M1: inokulum campuran akar segar; M2: inokulum campuran penyimpanan akar suhu ruang; M3: inokulum campuran penyimpanan akar suhu lemari pendingin; M4: inokulum G. clarum akar segar; M5: inokulum G. clarum penyimpanan akar suhu ruang; M6: inokulum G. clarum penyimpanan akar suhu lemari pendingin; M7: inokulum Acaulospora sp. akar segar; M8: inokulum Acaulospora sp. penyimpanan akar suhu ruang; M9: inokulum Acaulospora sp. penyimpanan akar suhu lemari pendingin; S1: media steril; S2: media tidak steril

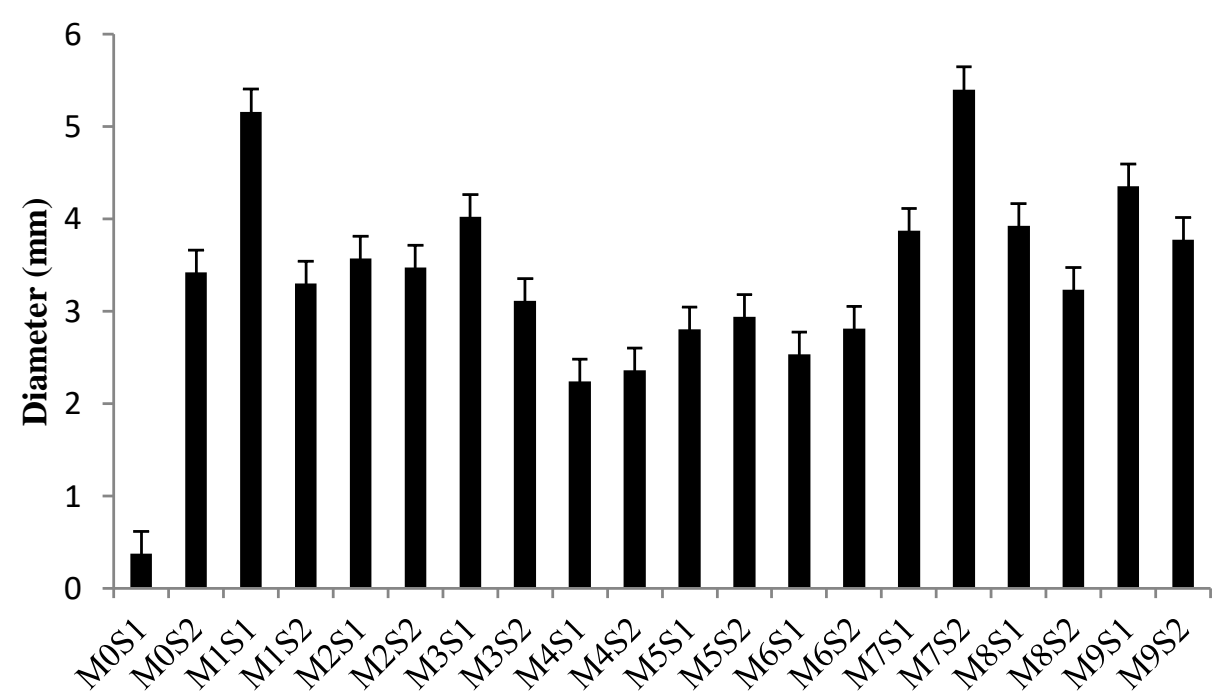

\section{Perlakuan}

Gambar 2 Pengaruh interaksi tipe inokulum dan media tanam terhadap pertambahan diameter bibit jati (Tectona grandis) umur 24 minggu setelah tanam; M0: tanpa inokulum; M1: inokulum campuran akar segar; M2: inokulum campuran penyimpanan akar suhu ruang; M3: inokulum campuran penyimpanan akar suhu lemari pendingin; M4: inokulum G. clarum akar segar; M5: inokulum G. clarum penyimpanan akar suhu ruang; M6: inokulum G. clarum penyimpanan akar suhu lemari pendingin; M7: inokulum Acaulospora sp. akar segar; M8: inokulum Acaulospora sp. penyimpanan akar suhu ruang; M9: inokulum Acaulospora sp. penyimpanan akar suhu lemari pendingin; S1: media steril; S2: media tidak steril 
Secara umum, inokulum akar FMA dapat memberikan pengaruh positif terhadap pertambahan tinggi dan diameter bibit jati dibandingkan dengan kontrol. Pada bibit jati yang diinokulasi inokulum akar campuran dan inokulum Acaulospora sp. terjadi peningkatan pertambahan tinggi bibit jati dibandingkan dengan bibit jati yang diinokulasi dengan inokulum akar G. clarum. Bibit jati yang diinokulasi inokulum akar campuran segar media steril (M1S1) memperlihatkan pertambahan tinggi yang lebih baik dibandingkan dengan inokulum akar Acaulospora sp. segar media steril (M7S1) dan inokulum akar G. clarum segar media steril (M4S1). Bibit jati yang diinokulasi dengan inokulum akar campuran simpan suhu ruang $26^{\circ} \mathrm{C}$ selama 2 minggu dengan media steril (M2S1) memberikan pertumbuhan yang tidak berbeda nyata dengan inokulum akar Acaulospora sp. simpan suhu ruang (M8S1). Hal yang sama ditunjukkan pada perlakuan inokulum akar campuran simpan suhu lemari pendingin $5^{\circ} \mathrm{C}$ selama 2 minggu dengan media steril (M3S1) yang tidak berbeda nyata dengan perlakuan inokulum akar Acaulospora sp. simpan suhu lemari pendingin $5^{\circ} \mathrm{C}$ selama 2 minggu pada media steril (M9S1). Perlakuan dengan penggunaan inokulum akar campuran segar meningkatkan tinggi bibit jati sebesar 68.18\% dibandingkan dengan kontrol. Danu et al., (2015) melaporkan bahwa inokulasi FMA campuran (Acaulospora sp., Gigaspora sp., Glomus sp.) 5 gram yang dikombinasikan dengan pemupukan NPK 1 g memberikan peningkatan relatif tertinggi pada tinggi jabon merah sebesar $273.27 \%$.

Interaksi inokulum FMA dan media tanam memberikan pengaruh terhadap pertambahan diameter (Gambar 2). Interaksi pertambahan diameter terbaik pada kombinasi perlakuan inokulum akar Acaulospora sp. segar pada media tidak steril (M7S2) sebesar $5.40 \mathrm{~mm}$ diikuti perlakuan inokulum akar campuran segar media steril (M1S1) sebesar $5.16 \mathrm{~mm}$. Perlakuan dengan penggunaan inokulum akar mampu meningkatkan diameter bibit jati sebesar $93.02 \%$ dibandingkan dengan kontrol. Rumondang dan Setiadi, (2011) melaporkan isolat FMA Glomus etunicatum dengan media pasir:tanah yang disterilkan memberikan pengaruh positif untuk respon pertumbuhan tinggi dan diameter bibit jati di persemaian.

\section{Biomassa pucuk dan akar tanaman (g)}

Biomassa menunjukkan kemampuan tanaman dalam mengambil unsur hara dari media tanam untuk menunjang pertumbuhannya (Karepesina, 2007). Berdasarkan analisis statistik, berat kering pucuk menunjukkan pengaruh sangat nyata dari faktor tunggal FMA dan interaksinya. Berat kering akar menunjukkan pengaruh sangat nyata dari faktor tunggal inokulum FMA, media tanam dan interaksinya. Interaksi yang menunjukkan berat kering pucuk tertinggi pada 24 MST yaitu perlakuan inokulum akar campuran segar media steril (M1S1) sebesar $6.62 \mathrm{~g}$. Berat kering akar tertinggi yaitu perlakuan kombinasi perlakuan inokulum akar Acaulospora sp. segar media tidak steril (M7S2) sebesar 18.61 gram.

Pengaruh interaksi tipe inokulum akar FMA dan media tanam terhadap BKP, BKA bibit jati umur 24 MST dapat dilihat pada Tabel 2 .

Tabel 2 Pengaruh interaksi tipe inokulum akar FMA dan media tanam terhadap BKP, BKA bibit Jati (Tectona grandis) umur 24 MST

\begin{tabular}{ccc}
\hline \multirow{2}{*}{ Perlakuan } & \multicolumn{2}{c}{ BKP } \\
\cline { 2 - 3 } & $0.02 \mathrm{k}$ & BKA \\
\hline M0S1 & $2.04 \mathrm{cdefgh}$ & $0.03 \mathrm{i}$ \\
\hline M0S2 & $6.62 \mathrm{a}$ & $3.16 \mathrm{def}$ \\
\hline M1S1 & $1.55 \mathrm{fghij}$ & $11.40 \mathrm{~b}$ \\
\hline M1S2 & $3.26 \mathrm{bc}$ & $2.58 \mathrm{efg}$ \\
\hline M2S1 & $2.45 \mathrm{bcdefg}$ & $3.08 \mathrm{def}$ \\
\hline M2S2 & $3.71 \mathrm{~b}$ & $3.55 \mathrm{cdef}$ \\
\hline M3S1 & $1.95 \mathrm{cdefgh}$ & $3.48 \mathrm{cdef}$ \\
\hline M3S2 & $0.29 \mathrm{jk}$ & $3.75 \mathrm{cde}$ \\
\hline M4S1 & $0.40 \mathrm{ijk}$ & $0.67 \mathrm{hi}$ \\
\hline M4S2 & $1.16 \mathrm{ghijk}$ & $0.27 \mathrm{hi}$ \\
\hline M5S1 & $1.72 \mathrm{defgh}$ & $1.58 \mathrm{gh}$ \\
\hline M5S2 & $0.90 \mathrm{hijk}$ & $2.23 \mathrm{fg}$ \\
\hline M6S1 & $1.61 \mathrm{efghi}$ & $0.71 \mathrm{hi}$ \\
\hline M6S2 & & $2.29 \mathrm{fg}$
\end{tabular}




\begin{tabular}{ccc}
\hline \multirow{2}{*}{ Perlakuan } & \multicolumn{2}{c}{ Variabel } \\
\cline { 2 - 3 } & $2.92 \mathrm{bcde}$ & BKA \\
\hline M7S1 & $6.54 \mathrm{a}$ & $4.32 \mathrm{~cd}$ \\
\hline M7S2 & $3.05 \mathrm{bcd}$ & $18.61 \mathrm{a}$ \\
\hline M8S1 & $2.79 \mathrm{bcdef}$ & $4.45 \mathrm{~cd}$ \\
\hline M8S2 & $2.80 \mathrm{bcdef}$ & $4.24 \mathrm{~cd}$ \\
\hline M9S1 & $3.43 \mathrm{~b}$ & $4.01 \mathrm{~cd}$ \\
\hline M9S2 & $4.69 \mathrm{c}$
\end{tabular}

Keterangan : M0: tanpa inokulum; M1: inokulum campuran akar segar; M2: inokulum campuran penyimpanan akar suhu ruang; M3: inokulum campuran penyimpanan akar suhu lemari pendingin; M4: inokulum G. clarum akar segar; M5: inokulum G. clarum penyimpanan akar suhu ruang; M6: inokulum G. clarum penyimpanan akar suhu lemari pendingin; M7: inokulum Acaulospora sp. akar segar; M8: inokulum Acaulospora sp. penyimpanan akar suhu ruang; M9: inokulum Acaulospora sp. penyimpanan akar suhu lemari pendingin; S1: media steril; S2: media tidak steril. BKP: berat kering pucuk; BKA: berat kering akar. Angka-angka yang diikuti oleh huruf yang sama pada kolom yang sama menunjukkan tidak berbeda nyata berdasarkan uji Duncan pada taraf $\alpha 5 \%$.

Hasil penelitian menunjukkan bibit jati yang diinokulasi inokulum akar campuran dan inokulum akar Acaulospora sp. dan ditanam pada media steril maupun tidak steril mempunyai biomassa tanaman yang lebih baik dibandingkan dengan bibit yang diinokulasi inokulum akar G. clarum dan tidak diinokulasi FMA. Hal yang sama juga ditunjukkan oleh Prayudyaningsih dan Sari, (2016), semai jati yang diinokulasi FMA Gigaspora sp., Acaulospora sp. dengan media yang dicampur kompos 5\% dan 15\% lebih baik dibandingkan dengan semai yang tidak diinokulasi FMA atau hanya ditanam pada media yang dicampur kompos. Penelitian Corryanti, (2007) menunjukkan bahwa inokulasi Gigaspora sp. memberikan respon yang baik pada pertumbuhan bibit jati dan memberikan respon perkembangan mikoriza lebih baik dibandingkan dengan bibit yang diinokulasi Glomus sp.

\section{Nisbah pucuk akar}

Nisbah pucuk akar menggambarkan kesetimbangan antara permukaan respiratif (tajuk) dan absorptif (akar). Pengaruh interaksi tipe inokulum akar FMA dan media tanam terhadap nisbah pucuk akar jati (Tectona grandis) umur 24 MST dapat dilihat pada Tabel 3.

Tabel 3 Pengaruh interaksi tipe inokulum akar FMA dan media tanam terhadap nisbah pucuk akar (NPA) jati (Tectona grandis) umur 24 MST

\begin{tabular}{cc}
\hline \multirow{2}{*}{ Perlakuan } & Variabel Pengamatan \\
\cline { 2 - 2 } & NPA \\
\hline M0S1 & $0.87 \mathrm{e}$ \\
\hline M0S2 & $1.05 \mathrm{cde}$ \\
\hline M1S1 & $1.03 \mathrm{cde}$ \\
\hline M2S1 & $1.05 \mathrm{cde}$ \\
\hline M2S2 & $1.25 \mathrm{abc}$ \\
\hline M3S1 & $1.08 \mathrm{cde}$ \\
\hline M3S2 & $1.24 \mathrm{abc}$ \\
\hline M4S1 & $1.00 \mathrm{cde}$ \\
\hline M4S2 & $1.09 \mathrm{cde}$ \\
\hline M5S1 & $1.42 \mathrm{a}$ \\
\hline M5S2 & $1.12 \mathrm{cde}$ \\
\hline M6S1 & $1.13 \mathrm{bcd}$ \\
\hline M6S2 & $1.35 \mathrm{ab}$ \\
\hline M7S1 & $1.11 \mathrm{cde}$ \\
\hline M7S2 & $1.07 \mathrm{cde}$ \\
\hline M8S1 & $0.92 \mathrm{de}$ \\
\hline & $1.10 \mathrm{cde}$ \\
\hline
\end{tabular}




\begin{tabular}{cc}
\hline \multirow{2}{*}{ Perlakuan } & Variabel Pengamatan \\
\cline { 2 - 2 } & NPA \\
\hline M8S2 & $1.08 \mathrm{cde}$ \\
\hline M9S1 & $1.09 \mathrm{cde}$ \\
\hline M9S2 & $1.10 \mathrm{cde}$ \\
\hline
\end{tabular}

Keterangan : M0: tanpa inokulum; M1: inokulum campuran akar segar; M2: inokulum campuran penyimpanan akar suhu ruang; M3: inokulum campuran penyimpanan akar suhu lemari pendingin; M4: inokulum G. clarum akar segar; M5: inokulum G. clarum penyimpanan akar suhu ruang; M6: inokulum G. clarum penyimpanan akar suhu lemari pendingin; M7: inokulum Acaulospora sp. akar segar; M8: inokulum Acaulospora sp. penyimpanan akar suhu ruang; M9: inokulum Acaulospora sp. penyimpanan akar suhu lemari pendingin; S1: media steril; S2: media tidak steril. NPA; nisbah pucuk akar. Angka-angka yang diikuti oleh huruf yang sama pada kolom yang sama menunjukkan tidak berbeda nyata berdasarkan uji Duncan pada taraf $\alpha 5 \%$.

Keseimbangan antara pertumbuhan atas dan pertumbuhan bawah terdapat pada interaksi perlakuan inokulum campuran penyimpanan akar suhu ruang media tanam steril (M2S1), inokulum campuran penyimpanan akar suhu lemari pendingin dengan media tanam steril (M3S1), inokulum G. clarum penyimpanan akar suhu lemari pendingin dengan media tanam steril (M6S1), inokulum G. clarum akar segar dengan media tanam tidak steril (M4S2). Beberapa perlakuan menunjukkan ketidakseimbangan hal ini diduga karena memiliki biomassa akar lebih besar dari tajuk. Duryea dan Brown, (1984) menyatakan bahwa bibit akan siap ditanam di lapang jika memiliki nilai NPA sebesar 1-3 dan yang terbaik adalah yang mendekati nilai minimum. Santosa et al., (2013) menyatakan semakin kecil nilai NPA maka semakin siap bibit tersebut untuk dipindahkan ke lapangan dikarenakan telah semakin tercukupinya jumlah akar yang akan dipergunakan dalam penyerapan air dan unsur hara guna menunjang pertumbuhan tanaman yang besar.

\section{Persentase Kolonisasi Akar}

Kolonisasi akar merupakan salah satu parameter untuk menentukan tingkat keberhasilan simbiosis antara FMA dengan tanaman inang. Hasil penelitian menunjukkan bahwa persentase kolonisasi FMA pada tanaman jati (Tabel 4) tergolong tinggi, sedang dan rendah berdasarkan kategori yang dibuat oleh O'Connor et al., (2001).

Tabel 4 Persentase kolonisasi akar bibit jati 24 MST

\begin{tabular}{ccc}
\hline \multirow{2}{*}{ Tipe Inokulum } & \multicolumn{2}{c}{ Persentase kolonisasi akar (\%) } \\
\cline { 2 - 3 } & S1 & S2 \\
\hline M0 & 14.67 & 47.67 \\
\hline M1 & 67.77 & 70.77 \\
\hline M2 & 73.33 & 80.22 \\
\hline M3 & 79.55 & 68.33 \\
\hline M4 & 39.55 & 17.22 \\
\hline M5 & 52.67 & 29.33 \\
\hline M6 & 0.33 & 38.77 \\
\hline M7 & 70.67 & 76.11 \\
\hline M9 & 13.11 & 38.22 \\
\hline
\end{tabular}

Keterangan : M0: tanpa inokulum; M1: inokulum akar campuran segar; M2: inokulum akar campuran simpan suhu ruang; M3: inokulum akar campuran simpan suhu kulkas; M4: inokulum akar Glomus clarum segar; M5: inokulum akar Glomus clarum simpan suhu ruang; M6: inokulum akar Glomus clarum simpan suhu kulkas; M7: inokulum akar Acaulospora sp. segar; M8: inokulum akar Acaulospora sp. simpan suhu ruang; M9: inokulum akar Acaulospora sp. simpan suhu kulkas; S1: media steril: S2: media tidak steril.

Hasil uji lanjut Duncan menunjukkan inokulum akar dapat menginfeksi akar dan menghasilkan kolonisasi berbeda pada setiap perlakuan. Persentase kolonisasi FMA tertinggi pada perlakuan M2S2 dengan nilai $80.22 \%$ dengan persen kenaikan sebesar $81.71 \%$ terhadap kontrol (M0). 


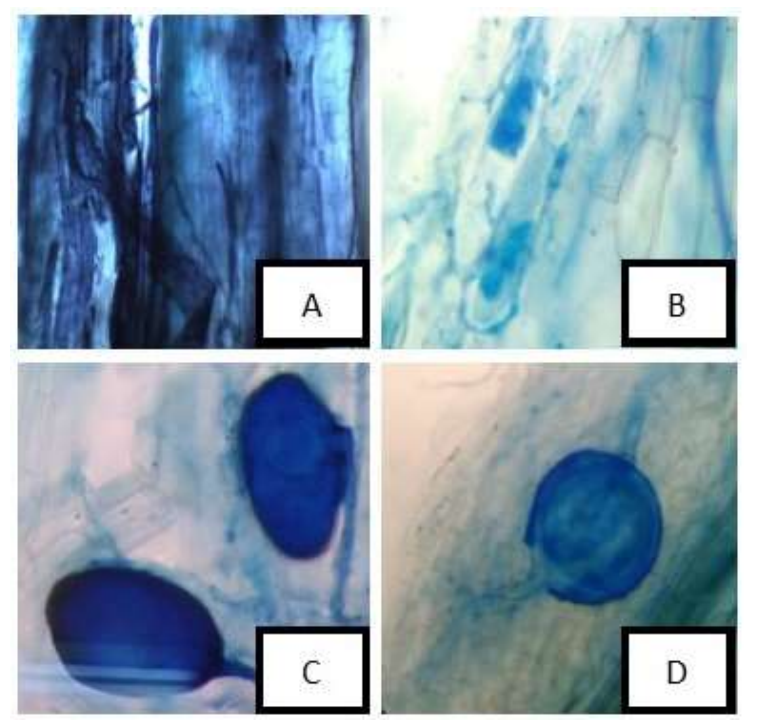

Gambar 3 Kolonisasi FMA pada akar tanaman jati (Tectona grandis) (A) hifa (B) arbuskula (C) vesikula (D) spora

Tingginya tingkat kolonisasi FMA tidak berhubungan dengan peningkatan pertumbuhan tanaman. Semakin tingginya persentase kolonisasi FMA tidak selalu diikuti dengan semakin tingginya respon pertumbuhan tanaman jati. Simbiosis antara FMA dan jati membentuk struktur yang lengkap pada jaringan akar mulai dari hifa, arbuskula, vesikula dan spora (Gambar 3). Hal tersebut menunjukkan bahwa tanaman jati merupakan tanaman inang yang responsif terhadap FMA. Warouw dan Kainde, (2010) melaporkan terdapat 4 genus FMA yang berasosiasi dengan tanaman jati yaitu Glomus, Acaulospora, Gigaspora dan Sclerocystis.

Simanungkalit et al., (2006) menjelaskan hifa terbentuk dari proses perkecambahan spora yang berperan dalam menyerap air dan unsur hara. Arbuskula merupakan struktur yang terbentuk dari cabang-cabang hifa intraradikular yang berada antara dinding sel dan membran sel yang berfungsi sebagai tempat pertukaran unsur hara dan karbon antara FMA dan tanaman inang. Vesikula merupakan struktur berdinding tipis yang terbentuk dari pembengkakan pada ujung hifa, berbentuk bulat, lonjong atau tidak teratur yang berfungsi sebagai organ penyimpanan cadangan makanan.

\section{SIMPULAN}

Inokulum akar bermikoriza dapat dijadikan sebagai sumber inokulum untuk pertumbuhan bibit jati. Inokulum akar segar lebih baik dibandingkan dengan inokulum akar simpan suhu ruang dan inokulum akar simpan suhu lemari pendingin $\left(5^{\circ} \mathrm{C}\right)$. Penyimpanan inokulum akar suhu ruang dan suhu lemari pendingin $\left(5^{\circ} \mathrm{C}\right)$ menurunkan efektivitas inokulum. Tipe inokulum akar campuran dan inokulum akar Acaulospora sp. memberikan pertumbuhan yang lebih baik dibandingkan dengan inokulum akar G. clarum.

\section{DAFTAR PUSTAKA}

Corryanti TWN, Soedarsono J, Radjagukguk B, Widyastuti SM. 2007. Perkembangan mikoriza arbuskula dan pertumbuhan bibit jati (Tectona grandis Linn. F) yang diinokulasi spora fungi mikoriza arbuskula asal tanah hutan tanaman jati. Jurnal Pemuliaan Tanaman Hutan. 1(2): 1-7.

Danu, Kurniaty R, Mindawati N. 2015. Penggunaan pupuk mikoriza dan pupuk NPK dalam pembibitan jabon merah (Anthocephalus macrophyllus (Roxb.) Havil). Balai Penelitian Teknologi Perbenihan Tanaman Hutan.

Daru TP, Sudarmadi, Setiadi Y, Riyanto, Abdullah L. 2007. Pengaruh tipe inokulan mikoriza arbuskula pada pertumbuhan rumput signal (Brachiaria decumbens Stapf.). Dalam: Prosiding seminar nasional mikoriza dalam kongres mikoriza ke-2, SEAMEO BIOTROP Bogor 17-21 Juli 2007. 
Duryea ML, Brown GN. 1984. Seedling Physiology and Reforestaion Success: Proceedlings of the Physiology Working Group Technical Session (Forestry Sciences). Dordrecht: Martinus Nijhoff Publishers.

Gutjahr C. 2014. Phytohormone signaling in arbuscular mycorhiza development. Journal Plant Biology. 20, 26-34.

Hajoeningtijas OD. 2009. Ketergantungan tanaman terhadap mikoriza sebagai kajian potensi pupuk hayati mikoriza pada budidaya tanaman berkelanjutan. Jurnal AGRITECH. XI (2):125-136.

Iffis B, Arnaud M, Hijri M. 2014. Bacteria associated with arbuscular mycorrhizal fungi within roots of plants growing in a soil highly contaminated with aliphatic and aromatic petroleum hydrocarbons. Journal FEMS Microbiol Lett. 358:44-54.

Kapulnik Y, Tsror L, Zipori I, Hazanovsky M, Wininger S, Dag A. 2010. Efeect of AMF application on growth. productivity and susceptibility to Verticillium wilt of lives grown under desert condition. Symbiosis. 52 (2-3): 103-111.

Khastini RO, Triadiati, Sukarno N. 2007. Pengaruh fosfor pada bawang daun hidroponik bermikoriza dan pemanfaatan limbahnya untuk pertumbuhan tapak dara. Dalam: Prosiding seminar nasional mikoriza dalam kongres mikoriza ke-2. SEAMEO BIOTROP Bogor 17-21 Juli 2007.

Karepesina S. 2007. Keanekaragaman fungi mikoriza arbuskula dari bawah tegakan jati ambon (Tectona grandis Linn. F) dan potensi pemanfaatannya. Tesis. Bogor: Sekolah Pascasarjana, Institut Pertanian Bogor.

Nusantara AD. 2011. Pengembangan Produksi Inokulan Fungi Mikoriza Arbuskula berbasis bahan alami dan pemanfaatannya untuk tanaman Jati (Tectona grandis). Disertasi. Bogor: Sekolah Pascasarjana, Institut Pertanian Bogor.

Nusantara AD, Bertham YH, Mansur I. 2012. Bekerja dengan Fungi Mikoriza Arbuskula. Bogor: SEAMEO BIOTROP.

O'Connor PJ, Smith SE, Smith FA. 2001. Arbuscular mycorrhizal associations in the southern Southern Simpson desert. Aust. J. Bot. 49:493-499.

Prayudyaningsih R, Sari R. 2016. Aplikasi fungi mikoriza arbuskula dan kompos untuk meningkatkan pertumbuhan semai jati (Tectona grandis Linn. F) pada media tanah bekas tambang kapur. Jurnal Penelitian Kehutanan Wallacea. 5(1):37-46.

Rillig MC, Wright SF, Eviner VT. 2002. The role of arbuscular mycorrhizal fungi and glomalin in soil aggregation: comparing effects of five plants species. Plant soil. 238: 325-333.

Rumondang J, Setiadi Y. 2011. Evaluasi aplikasi fungi mikoriza arbuskula dan respon pertumbuhannya terhadap jati (Tectona grandis Linn. F) di Persemaian. Jurnal Silvikultur Tropika. 2(3): 194-197.

Santosa AC, Harwati T, Siswadi. 2013. Pengaruh pemberian mikoriza arbuskula dan pupuk organik terhadap pertumbuhan bibit jati putih. Jurnal Inovasi Pertanian. 12(2): 53-66.

Simanungkalit RD, Saraswati R, Hastuti RD, Husen E. 2006. Bakteri Penambat Fosfat. Dalam: Simanungkalit RD, Suriadikarta DA, Saraswati R, Setyorini D, Hartatik W, Editor. Pupuk Organik dan Pupuk Hayati. Bogor: Badan Penelitian dan Pengembangan Pertanian.

Smith SE, Read DJ, 2008. Mycorrhizal Symbiosis (Third Edition). New York: Academica Press.

Smith SE, Facelli E, Pope S, Smith A. 2010. Plant performance in stressful environments: interpreting new and established knowledge of the roles of arbuscular mycorrhiza. Plant soil. 326:3-20.

Warouw V, Kainde RP. 2010. Populasi jamur mikoriza vesikular arbuskular (MVA) pada zone perakaran Jati. Jurnal Eugenia. 16(1):38-45. 